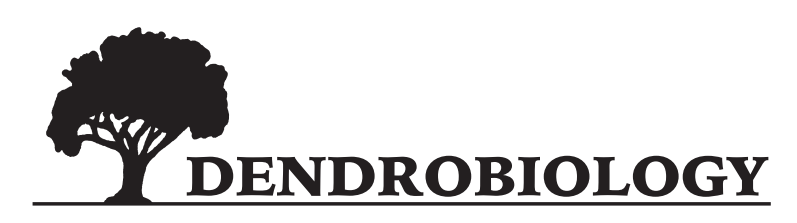

2017, vol. 77, 91-103

http://dx.doi.org/10.12657/denbio.077.008

\author{
Zbigniew Sierota, Joanna Ukalska, Marcin Zagożdżon, Sergii Boiko, \\ Marta Damszel, Anna Zawadzka, Cezary Bystrowski
}

\title{
Variation of bud flushing in Larix decidua clones
}

Received: 3 October 2016; Accepted: 31 January 2017

\begin{abstract}
In situ assessments of bud flushing in European larch Larix decidua Mill. clones growing under natural conditions were conducted in the Łęgajny seed orchard, Warmia-Masuria Province, Poland. The 27 assessed clones (among a total of 332 trees) were derived from superior plus trees from six selected stands in north eastern Poland. The analyses were carried out on 15-year-old clones grown in two seed orchard sectors differing in soil moisture conditions (no. 3, a nearly flat surface with southern exposure and no. 5 , a flat surface, slightly inclined toward the north and periodically flooded by nearby bog-springs). Apical and axillary bud flushing was assessed in March/April 2014, using a 6-stage scale. Significant differences in bud burst were observed among clones, bud types (apical or axillary), clone provenances and growing conditions in seed orchard sectors. Generally, axillary buds flushed earlier than apical buds. Clones growing in section no. 3 showed earlier bud flushing than in section no. 5. Daily mean temperature during the initial bud burst period (stages 0-3) had no significant effect on bud flushing in a number of clones, however the cumulative temperature in that period was strong correlated with bud flushing for particular clones and provenances which suggests susceptibility to spring frost. Local site conditions (i.e. different soil moisture contents and insolation levels between sectors) as well as decreased temperatures in the first period of bud development had strong effects on bud flushing in European larch clones.
\end{abstract}

Keywords: European larch, seed orchard, bud burst, temperature, generalized linear model

Addresses: Z. Sierota, University of Warmia and Mazury in Olsztyn, Dept. of Forestry and Forests Ecology, Plac Łódzki 2, 10-727 Olsztyn, Poland, e-mail: zbigniew.sierota@uwm.edu.pl A. Zawadzka, University of Warmia and Mazury in Olsztyn, Dept. of Forestry and Forests Ecology, Plac Łódzki 2, 10-727 Olsztyn, Poland, e-mail: anna.zawadzka@uwm.edu.pl

S. Boiko, University of Warmia and Mazury in Olsztyn, Dept. of Forestry and Forests Ecology, Plac Łódzki

2, 10-727 Olsztyn, Poland, e-mail: sergii.boiko@uwm.edu.pl

J. Ukalska, Warsaw University of Life Sciences, Faculty of Applied Informatics and Mathematics, Biometry Division, Nowoursynowska 159, 02-776 Warsaw, Poland, e-mail: joanna_ukalska@sggw.pl

M. Zagożdżon, Szczytno Forest District, e-mail: zag.marcin@wp.pl

M. Damszel, University of Warmia and Mazury in Olsztyn, Dept. of Entomology, Phytopathology and Molecular Diagnostics, Prawocheńskiego 17, 10-721 Olsztyn, Poland, e-mail: marta.damszel@uwm.edu.pl C. Bystrowski, Forest Research Institute, Department of Forest Protection, Sękocin Stary, Braci Leśnej 3, 05-090 Raszyn, Poland, e-mail: c.bystrowski@ibles.waw.pl 


\section{Introduction}

Studies on tree breeding have been carried out in a variety of forest tree species, with the aim of achieving the best progenies in terms of robustness, desirable propagation characteristics and timber quality (Karki et al., 2000). Modern forestry uses seed orchards as a common means for producing genetically improved seed material for the establishment of new forests (Matras, 2001). These intensively managed plantations facilitate the mass production of seeds from either clones (vegetative copies) or sexual progenies of plus trees selected for their superior phenotypes (Jagielska, 2008). In addition to their fundamental role in the production of selected genetic materials and gene conservation, seed orchards support research on many traits of bred trees, including morphological features, growth characteristics, fruit production and resistance to frost, insect pests and diseases (Hansen, 1992). The European larch (Larix decidua Mill.) plays a vital role in forest ecosystems in Poland and is therefore an important subject of genetic studies (Szeligowski \& Bolibok, 2008).

Variability of European larch features, such as frost resistance, vitality and timber quality, not only relies upon genetic variation (Hansen, 1992; Andrzejczyk \& Bellon, 1999), but also on climatic factors that can promote or limit plant growth. According to Migliavacca et al. (2008), larch ecology is affected by various factors that influence its phenology, especially air temperature and photoperiod. Furthermore, Moser et al. (2010) observed adverse effects of elevation on the length of the vegetation period in larch plantations. The European larch is highly tolerant to various thermal conditions, including frost; yet, air temperature is a key factor in the elongation of larch shoots (Häkkinenn, 1995; Wilczyński \& Wertz, 2012). Several studies have shown that air temperatures during both winter and early spring months influence the development of larch needles (Hänninen, 1995; Chuine \& Cour, 1999; Chmielewski \& Rötzer, 2001; Rötzer et al., 2004; Migliavacca et al., 2008). Studies on annual growth of larch trees have been conducted in Europe, including studies in Italy and Finland that described the development of larch needles (Rossi et al., 2009) as well as the role of cumulative temperature and latitude on shoot growth in Larix sibirica and Larix gmelinii (Lukkarinen et al., 2013).

The effects of environmental factors (especially air temperature) have also been taken into account in the selection process of European larch genetic material with lower vulnerability to fungal infection or endophytes (Szumowski, 1995; Kauhanen et al., 2006; Kulej, 2006). Wind and the loose planting of trees increase needle sensitivity at low air temperatures, changing their colour, which is often mistaken for fungal infection or pest attacks. When vegetation growth occurs early in the season, this phenomenon initiates defence mechanisms and the regeneration of the assimilation apparatus (Jalkanen, 2016). Rehfeldt (1995) reported that precipitation can enhance the susceptibility of young needles to the fungus Rhabdocline laricis (Vuill.) Stone (syn. Meria laricis Vuill.); this has also been observed by Jalkanen (2016) in the case of Hypodermella laricis Tub. Telford et al. (2015) also indicated that genetic variation within tree species determines their resistance to pathogens and frost, which help to identify resistant clones in plantations, despite some loss of environmental adaptations.

Intense research activities have been conducted for years in Poland to enhance the productive potential and stability of future generations of forests. This is exemplified by the recent 'Program of conserving forest genetic resources and breeding of trees in Poland for the years 2011-2035' (an initiative of forest tree genetics experts from the Forest Research Institute in cooperation with the State Forests). The program includes the selection of breeding populations with wide-ranging abilities to serve various forest functions as well as the protection of Polish forests against genetic migration of reproductive material that is poorly adjusted to Polish environmental conditions (Jagielska, 2008). Selective breeding of the European larch has been embraced by the Program as a vital aspect for the long-term development of Poland's forest resources.

Selected seed stands of European larch were established in several of Poland's regions with different site conditions, with the aim of distinguishing the best phenotypic traits of given provenances, e.g. Larix decidua subsp. polonica (Racib.) Domin in the Świętokrzyskie Mts. (southeastern Poland). The Łęgajny seed orchard was established in northern Poland and contains $L$. decidua clones of different provenances throughout the Warmia-Masuria region (forests under management of the Regional Directorate of State Forests Olsztyn). The seed orchard has become a research site for studying various European larch phenotypic traits, including frost resistance (Hansen, 1992) and timber quality (Wilczyński \& Wertz, 2012). Although phenology plays a significant role in larch productivity (Gauchat \& Pâques, 2011), it has not yet been studied using the available European larch clones growing under the natural conditions of northern Poland.

Accordingly, the aim of the present study was to assess differences in bud flushing between European larch Larix decidua clones under natural conditions of a seed orchard in the Warmia-Masuria region. We presumed that air temperature has a significant effect on the rates of flushing of apical (terminal) and axillary (lateral) buds and might be mediated by clone origin (provenance). 


\section{Methods}

\section{Seed orchard}

The study was conducted in 2014 in a European larch (Larix decidua Mill.) seed orchard, established in 1999 by the Forest Research Institute (IBL, Poland) in collaboration with the Forest District Olsztyn, within the Forest Division Wadąg (Łęgajny: 53 $48^{\prime}$ $52.62^{\prime \prime} \mathrm{N} ; 20^{\circ} 36^{\prime} 36.50^{\prime \prime}$ E). The seed orchard comprises an area of 14.25 ha, divided into 13 sectors, in which 2,769 one-year-old grafts were planted on a $6 \times 6 \mathrm{~m}$ grid (grafting was performed from January to February 1998 on two-year-old European larch stock) and grown in agro-forestry conditions. European larch clones were derived from 32 plus trees of 6 provenances selected from forest stands managed by the Regional Directorates of the State Forests Olsztyn and Gdańsk.

For the purpose of the present study, two seed orchard sectors were selected (no. 3 and no. 5, Fig. 1 ), which were dissimilar in the growth conditions of the grafts. The differences were a result of widely divergent soil moisture values between the sectors, caused by periodical flooding of sector no. 5 due to surface outflows of ground waters (from northerly situated bog-springs at the edge of sector 7). Moreover, the area of sector no. 3 was slightly inclined toward the south.

\section{Research material}

In total, 332 European larch specimens were examined (212 in sector no. 3 and 120 in sector no. 5). They represented 27 clones derived from plus trees growing in selected seed stands (provenances) across six forest districts: (1) Elbląg, (2) Młynary, (3) Dobrocin, (4) Stare Jabłonki, (5) Nowe Ramuki and (6) Strzałowo (Fig. 1). Plus trees from FD Elbląg and FD Młynary (30-150 $\mathrm{m}$ a.s.l.) grow under weather conditions affected by the Baltic Sea climate, i.e. in this region, cumulative annual precipitation is 600 $650 \mathrm{~mm}$ and mean annual temperature is $+7^{\circ} \mathrm{C}$. Selected plus trees from FD Dobrocin, FD Stare Jabłonki and FD Nowe Ramuki (60-180 m a.s.l.) grow in the Masuria Lakes climatic region, with a mean annual temperature of $+7.5^{\circ} \mathrm{C}$ and cumulative annual precipitation of $550-600 \mathrm{~mm}$. Climatic conditions in FD Strzałowo (130 m a.s.l.) are comparable, i.e. cumulative annual precipitation of $500-630 \mathrm{~mm}$ and mean annual temperature of $7-7.7^{\circ} \mathrm{C}$. In general, in the region where all the aforementioned European larch stands grow, the annual number of rainy days is 160-170, with a vegetation period of approximately 190-200 days (Kondracki, 2013). All the plus trees used for cloning were about 100-150 years old and $30-40 \mathrm{~m}$ high, with a DBH of $55-80 \mathrm{~cm}$ (data from the Forest District Olsztyn).

\section{Temperature measurement}

Within the two seed orchard sectors examined (i.e. no. 3 and no. 5), temperature was measured using three HOBO UA 002-64 data loggers (Onset Computer Corporation, Bourne, MA, USA). These were fixed $2 \mathrm{~m}$ above the ground in central regions of the sectors (no. 3, one data logger in the shade and one in sunlight; no. 5, one data logger in the shade only). Temperature records (taken every hour from March 19-April 26) were downloaded and the recorded values were computed as the daily averages for the two sectors. Mean daily temperature and values of the cumulative temperature (sum temperatures) over the tested periods $0-1$ to $0-5$ were used in further calculations (Schueler \& Liesebach, 2016).

\section{Bud flushing assessment}

The term "bud" is used for apical (terminal) or axillary (lateral) protuberances that develop into

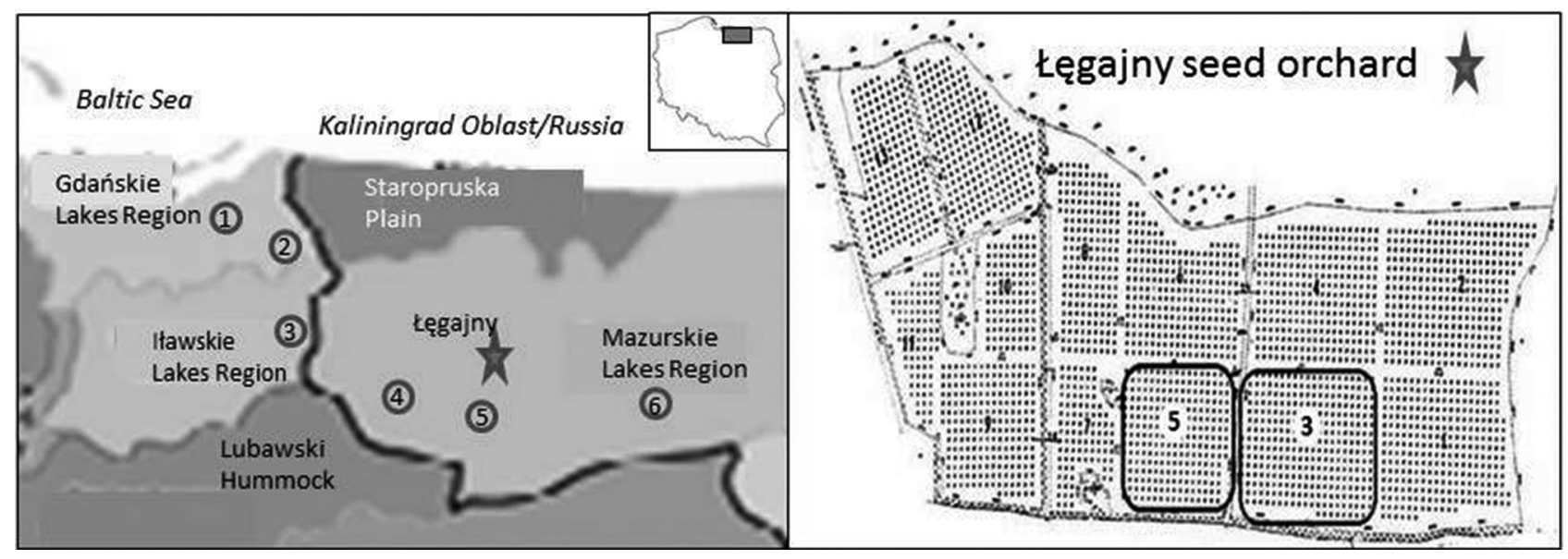

Fig. 1. Localities of the selected European larch parental tree stands (1-6), showing climate macroregions in northern Poland (after Kondracki, 2013) and map of the Łęgajny seed orchard (image adapted from the IBL map archive) 

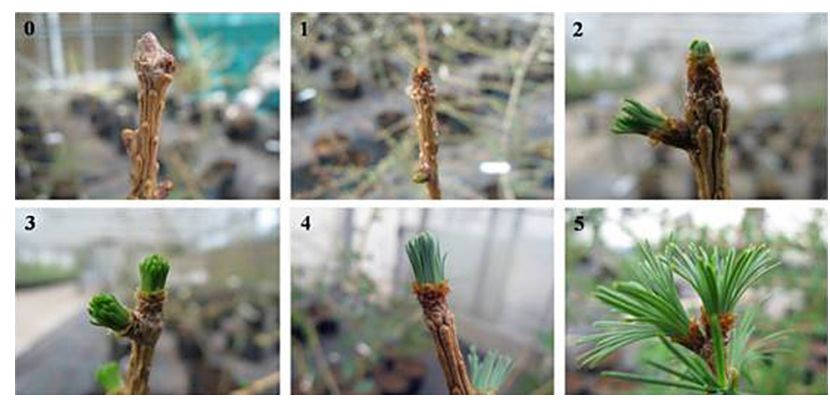

Fig. 2. Reference scale used in bud flushing assessments (reproduced from Gauchat and Pâques, 2011, with consent of the authors)

reproductive cones, leaves or shoots (Owens \& Molder, 1979). For each tree, two opposite lateral shoots were randomly selected from the crown at $3 \mathrm{~m}$ above ground level and marked. Evaluation of bud burst was performed using the 6-stage scale for apical bud flushing assessment (Gauchat \& Pâques, 2011): 0, dormant bud; 1, bud swollen and whitish; 2, visible needles in the bud; 3 , closed spindle-shaped needles; 4 , needles completely unfolded, up to $1 \mathrm{~cm}$ in length, but still spindle-shaped; 5 , elongated needles $1-2 \mathrm{~cm}$ in length, in an open rosette (Fig. 2).

Bud flushing assessments were conducted from 19 March to 24 April 2014 (over 37 days), from the start of dormant bud development (i.e. stage 1) in early spring to the open rosette stage in all grafts in the clones. Inspection of apical and all axillary buds on each shoot examined was performed every two days between 19 March and 17 April and every four days between 18 April and 24 April. The numerical values assigned to bud flushing stages ( $0-5$ scale, Fig. 3 ) were averaged for each bud type per tree, and the arithmetic means (for five to eight trees per clone) were calculated for all trees of a given clone within each sector observed (no. 3 and no. 5). The number

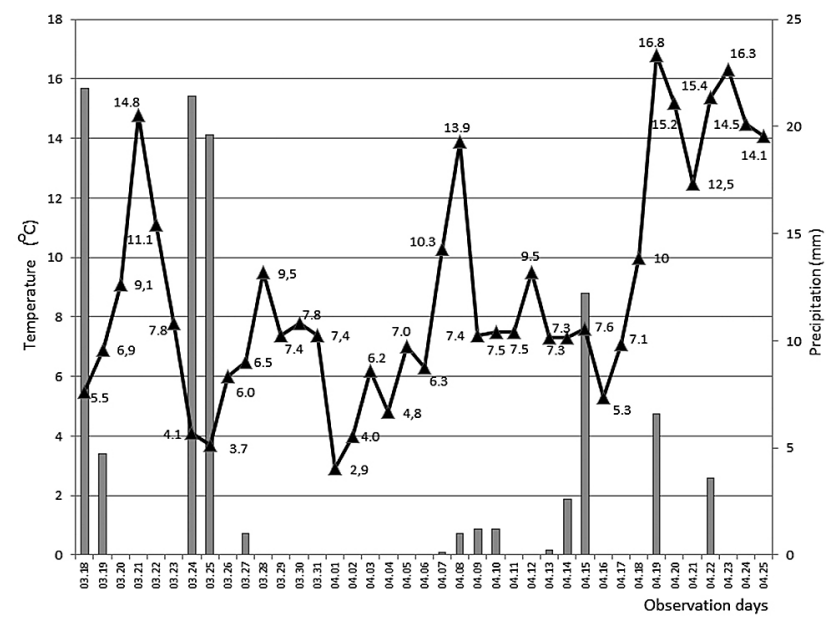

Fig. 3. Mean daily air temperatures (line) and precipitation (bars) in the Łęgajny seed orchard in spring 2014. Temperature values are the daily means from two data loggers of days to reach particular stages was calculated and clones in stages $0-5$ were compared.

\section{Statistical analysis}

Bud flushing dynamics and differences between apical and axillary bud burst in each sector, as well as differences between clones, were tested according to the following general and generalized linear models (Nelder \& Weddenburn, 1972; McCullagh \& Nelder, 1989):

Model 1: $\log \left(N d_{i j k l}\right)=M_{i}+C_{j}\left(M_{i}\right)+S_{k}+B_{l}+$ $C_{j}\left(M_{i}\right) \times B_{l}+S_{k} \times B_{l}$,

where $\log \left(N d_{i j k l}\right)$ is the canonical link function; $N d_{i j k l}$ is the mean number of days for achieving the final stage of bud development; $i, j, k$ and $l$ represent the $i$ th, $j$ th, $k$ th and $l$ th provenance, clone, sector and bud type, respectively; $M_{i}$ is the clone origin main effect (for parental provenance $i=1, \ldots, 6) ; C_{j}\left(M_{i}\right)$ is the main effect of $j$ th clone $(j=1, \ldots, 31)$ nested within $i$ th origin provenance; $S_{k}$ is the sector main effect $(k=1,2) ; B_{l}$ is the bud-type main effect $(l=1$, 2); $C_{j}\left(M_{i}\right) \times B_{l}$ is the interaction effect between clone (nested within an origin provenance) and bud type and $S_{k} \times B_{l}$ is the interaction effect between sector and bud type.

The goodness of this model's fit was favoured by the Akaike information criterion (Akaike, 1983). The distribution of variable $\mathrm{Nd}$ was modelled both with a Poisson distribution and a negative binomial distribution, but a better fit was obtained using the Poisson distribution. The significance of the model effects was tested with the likelihood-ratio chi-squared statistic for a type 3 analysis.

Model 2: $\operatorname{Tcum}_{i j k l}=M i+C_{j}\left(M_{i}\right)+S_{k}+B_{l}+C_{j}\left(M_{i}\right)$ $\times B_{l}+S_{k} \times B_{l}+e_{i j k l}$

where Tcum $_{i k l}$ is the cumulative temperature for achieving the final stage of bud development; $e_{i j k l}$ is the error term; the other parameters of Model 2 are the same as in Model 1.

Model 3: Dap - ax $x_{i j k}=M_{i}+C_{j}\left(M_{i}\right)+S_{k}$,

where Dap - ax $x_{i j k}$ is the difference between apical and axillary bud number of days/temperature sum required to achieve the final stage of bud development for each tree; the other parameters of Model 3 are the same as in Models 1 and 2.

The Shapiro-Wilk test was used to determine if residuals of Models 1-3 were normally distributed. Based on Tukey's HSD test, homogeneous groups were determined for the significant models' effects.

The analyses were performed using the statistical software SAS 9.3 (SAS Institute Inc., Cary, NC, USA). We used the procedures GENMOD (Stokes et al., 2000; Littell et al., 2002) for Model 1 and GLM for Models 2 and 3. 


\section{Results}

\section{Weather conditions}

Mean daily temperatures averaged across the two sectors of the seed orchard are presented in Figure 3. During the observation period, mean daily temperatures fell below $5^{\circ} \mathrm{C}$ on five days (March 24 and 25; April 1, 2 and 4).

Over the 37 observation days, mean daily air temperatures ranged from $2.9^{\circ} \mathrm{C}$ (1 April) to $16.8^{\circ} \mathrm{C}$ (19 April). Temperature was changing at the end of March and at the beginning and middle of April (Fig. 4). Between these periods, daily temperatures were lower again (e.g. $2.9^{\circ} \mathrm{C}$ on 1 April and $5.3^{\circ} \mathrm{C}$ on 17 April). The cumulative temperatures recorded within the observation period until the last day of the observation by each of the data loggers used was as follows: sector no. 3 , data logger in shade, $349.91^{\circ} \mathrm{C}$; sector no. 5 , data logger in shade, $360.77^{\circ} \mathrm{C}$. In sector no. 5 , the so-called "cold air lake" did not decrease cumulative temperatures in relation to logging in sunlight; the logger was installed at a height of $2 \mathrm{~m}$ and, contrary to our expectation, cumulative temperature was $11.86^{\circ} \mathrm{C}$ higher.

Over the same time interval, total precipitation was moderately low, with rainy days prevailing around mid-March. Total precipitation in March was $39.12 \mathrm{~mm}$, whereas in the relatively dry April, total precipitation was lower $(28.17 \mathrm{~mm})$. On 24 and 25 March, the temperature dropped to $4.1-3.7^{\circ} \mathrm{C}$, with a precipitation of 21.4 and $19.6 \mathrm{~mm}$, respectively (Fig. 4). Relationships between temperature change and rainfall in the study period appear to be mirror images of each other-on all rainfall days, air temperature decreased notably.

\section{Bud flushing in phases 0-4}

During the first four observation days, many apical and axillary buds were assessed as swollen, without needles protruding visibly (Table 1). Differentiation of bud flushing stages between clones was observed no earlier than on the second day for apical buds on the 3077 Dobrocin clone and on the third day of assessment for axillary buds on the 3082 Elbląg clone,

Table 1. Mean number of days from state 1 to state 4 of apical (Ap) and axillary (Ax) bud development of tested clones.

Fast-developing buds in first phase of growth (0-3) are in bold and slow-developing buds are in italics

\begin{tabular}{|c|c|c|c|c|c|c|c|c|c|}
\hline Provenance & Clone & Ap 0-1 & Ax 0-1 & Ap 0-2 & Ax 0-2 & Ap 0-3 & Ax 0-3 & Ap 0-4 & Ax 0-4 \\
\hline Dobrocin & 3076 & 1.3 & 1.3 & 13.8 & 8.0 & 21.3 & 12.0 & 24.6 & 16.0 \\
\hline Dobrocin & 3077 & 0.1 & 0.7 & 8.0 & 6.7 & 10.8 & 9.4 & 19.8 & 14.9 \\
\hline Dobrocin & 3078 & 0.6 & 0.6 & 11 & 6.6 & 17.6 & 9.9 & 22.1 & 13.3 \\
\hline Dobrocin & 3079 & 1.1 & 1.1 & 11.6 & 7.3 & 17.6 & 11.8 & 22.0 & 14.8 \\
\hline Elbląg & 2925 & 1.6 & 1.6 & 4.2 & 3.3 & 9.6 & 7.6 & 14.3 & 12.6 \\
\hline Elbląg & 2926 & 1.8 & 1.8 & 8.2 & 7.6 & 13.6 & 11.4 & 19.6 & 18.6 \\
\hline Elbląg & 2927 & 1.4 & 1.4 & 7.4 & 7.0 & 10.6 & 9.8 & 18.2 & 16.2 \\
\hline Elbląg & 3081 & 1.8 & 1.6 & 10.2 & 8.7 & 17.2 & 13.8 & 21.3 & 18.4 \\
\hline Elbląg & 3082 & 0.3 & 0.3 & 4.9 & 3.3 & 7.5 & 7.0 & 12.6 & 9.9 \\
\hline Elbląg & 3296 & 0.5 & 0.5 & 3.9 & 2.5 & 8.3 & 7.3 & 12.6 & 11.9 \\
\hline Młynary & 2851 & 0.7 & 0.7 & 9.0 & 7.4 & 14.3 & 10.7 & 21.3 & 16.9 \\
\hline Młynary & 2860 & 0.9 & 0.9 & 8.2 & 6.8 & 14.6 & 9.7 & 20.6 & 15.8 \\
\hline Młynary & 2862 & 2.7 & 2.7 & 8.1 & 7.3 & 15.2 & 12.2 & 20.6 & 17.6 \\
\hline Młynary & 2863 & 2.6 & 2.0 & 8.6 & 7.0 & 12.0 & 9.1 & 17.7 & 16.2 \\
\hline Młynary & 2864 & 1.0 & 0.6 & 10.3 & 7.3 & 17.3 & 10.0 & 22.2 & 13.9 \\
\hline Młynary & 2865 & 0 & 0 & 8.3 & 7.0 & 13.8 & 9.0 & 18.7 & 14.1 \\
\hline Młynary & 2866 & 1.3 & 0.9 & 8.4 & 6.0 & 13.7 & 9.1 & 19.8 & 13.6 \\
\hline Młynary & 2867 & 0.9 & 0.5 & 11.0 & 7.1 & 18.0 & 9.4 & 21.6 & 12.4 \\
\hline Młynary & 2868 & 1.1 & 1.1 & 7.4 & 6.1 & 12.8 & 11.0 & 18.5 & 14.4 \\
\hline Młynary & 2919 & 0.3 & 0.3 & 8.4 & 6.7 & 13.3 & 9.1 & 20.3 & 12.1 \\
\hline Młynary & 2920 & 0.4 & 0.4 & 6.0 & 5.8 & 9.0 & 8.2 & 16.6 & 12.6 \\
\hline Młynary & 2921 & 0.5 & 0.5 & 7.6 & 6.4 & 15.1 & 9.5 & 19.6 & 16.4 \\
\hline Nowe Ramuki & 2549 & 0.7 & 0.7 & 9.4 & 8.0 & 16.4 & 13.3 & 22.4 & 17.3 \\
\hline Nowe Ramuki & 2550 & 1.6 & 1.6 & 5.5 & 4.3 & 10.9 & 9.4 & 17.2 & 16.0 \\
\hline Nowe Ramuki & 2551 & 0 & 0 & 6.2 & 5.8 & 11.2 & 9.8 & 16.2 & 14.6 \\
\hline Stare Jabłonki & 2514 & 0.6 & 0.6 & 7.6 & 6.7 & 14.6 & 10.1 & 19.9 & 13.8 \\
\hline Stare Jabłonki & 2515 & 1.1 & 1.1 & 13.1 & 8.4 & 19.4 & 14.4 & 25.5 & 19.3 \\
\hline Stare Jabłonki & 2516 & 1.9 & 1.6 & 8.1 & 6.9 & 12.2 & 10.0 & 18.8 & 16.3 \\
\hline Stare Jabłonki & 2231 & 1.0 & 1.0 & 6.6 & 6.2 & 11.4 & 8.8 & 16.6 & 15.0 \\
\hline Strzałowo & 3083 & 1.7 & 1.7 & 7.7 & 6.7 & 12.6 & 10.3 & 17.6 & 16.6 \\
\hline Strzałowo & 3084 & 0.7 & 0.5 & 7.7 & 6.0 & 13.0 & 10.2 & 19.2 & 14.9 \\
\hline
\end{tabular}




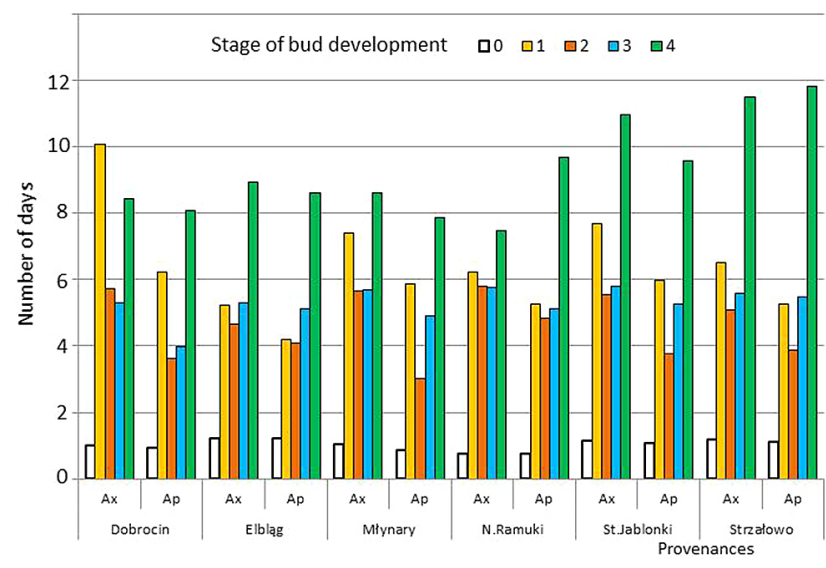

Fig. 4. Number of days to obtain a successive stage (0-4) for axillary (Ax) and apical (Ap) bud development of larch clones. Values represent means for each provenance

when daily air temperature $\left(3.7^{\circ} \mathrm{C}\right)$ was relatively low (Fig. 3).

The first phase (0-3) of bud development is highly susceptible to spring frost. We assumed that 80 and $120 \%$ of the average bud development period indicate 'fast' and 'slow' developing' buds, respectively, where 'fast' for apical buds (Ap) is $<10$ days and $<$ 8 days for axillary buds (Ax), while 'slow' for apical buds means $>16$ and for axillary buds $>12$ days.

Both bud types of clones 3081 from Elblag and 2515 from Stare Jabłonki were characterised as slow-developing. In contrast, both bud types of clones 2925, 3082 and 3296 from Elblag quickly reached stage 3, as did the apical buds of clone 2920 from Młynary. Full development (stage 5) of axillary buds was attained most quickly by clones 2867 and 2919 from Młynary and, again, by clone 2925 from Elblag, which was the fastest one to develop to stage 3 . These clones are likely to be susceptible to spring frost.

Among provenances, the average number of days to obtain the successive stages 1 and 2 in the development of both bud types differed, particularly in the beginnings of the stages 1-3 (Fig. 4). In Dobrocin provenance clones, the duration of stage 1 for axillary buds was the longest (10 days), in contrast to the shortest duration of stage 1 for axillary buds on Elblag clones (4 days). Stage 3 for apical buds was the shortest for Dobrocin clones and the longest one for Stare Jabłonki (Fig. 4).

The results show that axillary buds responded more rapidly to higher spring temperatures than apical buds. Overall, in sector no. 3, axillary buds developed more quickly than in sector no. 5 , especially from March 19-30. In contrast, in sector no. 5, there were no differences in bud development from the first day of the assessment onwards.

We observed differences in the timing of the achievement of flushing to a particular stage. For example, to reach stage 2.0 (i.e. $40 \%$ development

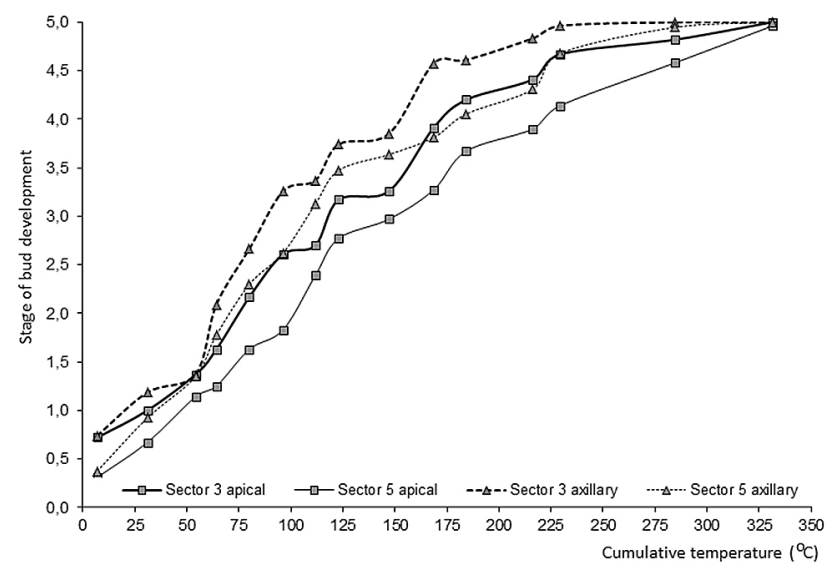

Fig. 5. Stage of bud flushing of European Larch in two sectors of the Łęgajny seed orchard (no. 3 and 5) and cumulative temperature

within the bud flushing scale) in sector no. 3, axillary buds took eight days (stage was reached on 26 March, almost contemporaneous with the apical buds). In sector no. 5, however, axillary buds reached stage 2 four days earlier than apical buds (28 March and 1 April, respectively; observation days 9 and 13, respectively). To reach stage 4 (i.e. $80 \%$ development), the longest period, seven days between both sectors, was noted for the apical buds (Fig. 5). Variation in the development between the sectors could be observed from stage 1.0 onward for apical buds and from stage 1.5 onward for axillary buds.

For a period of 19 observation days (from 24 March to 7 April), apical buds in sector no. 3 showed a higher rate of flushing when compared to those examined in sector no. 5. Starting on 9 April (observation day 21 ), daily air temperatures were considerably lower, and during the following seven days, the rate of bud flushing was much lower. This slowdown in bud development could have been caused by the stable average air temperature over this period or, alternatively, the sigmoid character of development over time.

\section{Temperature and bud flushing relationships in stage 5}

In terms of number of days for achieving the final stage of bud development, the effects specified in Model 1 were significant (Table 2). The longest period (37 days) needed for achieving stage 5 (elongated needles, 1-2 cm long in an open rosette) was observed in three specimens of clone 2862, derived from a plus tree growing in Młynary. The mean number of days for reaching stage 5 by all the buds observed for this clone was 33 (flushing of apical buds occurred after 34.5 days on average and that of axillary buds after 31.4 days; Table 3). The fastest axillary bud burst (open rosette and elongated needles 
Table 2. Influence of effects specified in Models 1 and 2 on bud development dynamics (Nd - number of days; Tcum - cumulated temperature; Num DF - numerator degree of freedom; Den DF - denominator degree of freedom; Chi-square, F - test statistics; $p$ - p value)

\begin{tabular}{|c|c|c|c|c|c|c|}
\hline \multirow{2}{*}{ Source of variation } & \multirow{2}{*}{ Num DF } & \multirow{2}{*}{ Den DF } & \multicolumn{2}{|c|}{$\mathrm{Nd}$} & \multicolumn{2}{|c|}{ Tcum } \\
\hline & & & Chi-square & $\mathrm{p}$ & $\mathrm{F}$ & $\mathrm{p}$ \\
\hline Provenance of plus tree $M$ & 5 & 588 & 88.08 & $<0.001$ & 14.82 & $<0.001$ \\
\hline Clone(provenance) $C(M)$ & 25 & 588 & 238.01 & $<0.001$ & 9.04 & $<0.001$ \\
\hline Sector $S$ & 1 & 588 & 142.62 & $<0.001$ & 125.73 & $<0.001$ \\
\hline Bud type $B$ & 1 & 588 & 138.69 & $<0.001$ & 167.34 & $<0.001$ \\
\hline Clone(provenance) $\times$ Bud type $C(M) \times B$ & 30 & 588 & 130.65 & $<0.001$ & 4.02 & $<0.001$ \\
\hline Sector $\times$ Bud type $S \times B$ & 1 & 588 & 10.95 & $<0.001$ & 2.29 & 0.131 \\
\hline
\end{tabular}

within 22.3 days) was observed in specimens of clone 3082 from Elbląg. These clones achieved the last developmental stage (elongated needles $1-2 \mathrm{~cm}$, in open rosette) 15 days earlier than the slowest-developing specimen, clone 2862 from Młynary, which achieved stage 5 within 37 days (Table 3 ).

Apical buds of the examined specimens of clone 3296 from Elbląg completed development (achieved stage 5) within the shortest period of time (22.39 days).

On average, European larch clones derived from plus trees from selected stands in Strzałowo and Stare Jabłonki showed latest significantly later date of full bud burst when compared to clones of other provenances (Tables 3 and 4). However, analysing the periods of the initial stages of bud development

Table 3. Means, standard errors (SE) and homogeneous groups of clones in terms of finishing bud flushing (in days, Nd, and cumulative temperature, $\mathrm{T}_{\text {cum }}$ )

\begin{tabular}{|c|c|c|c|c|c|c|c|}
\hline \multirow{2}{*}{$\begin{array}{l}\text { Clone } \\
\text { No. }\end{array}$} & \multirow{2}{*}{$\begin{array}{l}\text { Provenance of } \\
\text { plus tree }\end{array}$} & \multicolumn{3}{|c|}{$\mathrm{Nd}($ mean $\pm \mathrm{SE})$} & \multicolumn{3}{|c|}{$\mathrm{T}_{\text {cum }}($ mean $\pm \mathrm{SE})$} \\
\hline & & All buds & Apical buds & Axillary buds & All buds & Apical buds & Axillary buds \\
\hline 2862 & Młynary & $32.91 \pm 0.94 \mathrm{~A}^{1}$ & $.53 \pm 1.36 \mathrm{a}^{2}$ & $0 \mathrm{a}$ & $269.4 \pm$ & $\pm 11.6 \mathrm{a}$ & 11.6 \\
\hline 2516 & are & $5 \mathrm{AB}$ & & & $6 \mathrm{AB}$ & & \\
\hline 3083 & & $60 \pm 0$ & $2 \mathrm{a}$ & & $\mathrm{ABC}$ & $266 \pm$ & \\
\hline 2926 & & & & & $\mathrm{BC}$ & & \\
\hline 2515 & are Ja & $31.44 \pm 0.88 \mathrm{ABC}$ & $34.00 \pm 1.29 \mathrm{a}$ & & $253.7 \pm 7.9 \mathrm{ABC}$ & & \\
\hline & & & & & & & \\
\hline 2231 & are & $3 \mathrm{C}$ & & & $3 \mathrm{CD}$ & & $2.9 \mathrm{a}$ \\
\hline 2550 & $\therefore$ & C & & & $\mathrm{CD}$ & & \\
\hline 2851 & & $\mathrm{D}$ & & & $\mathrm{DE}$ & & \\
\hline 3084 & & & & & & & \\
\hline 30 & & & & & $\mathrm{DE}$ & & \\
\hline 3076 & & & & & & & \\
\hline 2864 & & & & & & & \\
\hline 2549 & ki & $\mathrm{D}$ & & & & & \\
\hline 2514 & & & & & & & \\
\hline 2919 & & & & & & & \\
\hline 3079 & & & & & $\mathrm{DE}$ & & \\
\hline 2863 & & & & & $\mathrm{DE}$ & & \\
\hline 30 & & & & & $\mathrm{DE}$ & & \\
\hline 2927 & & & & & FG & & $6 \mathrm{a}$ \\
\hline 2860 & & CDE & & & DEFG & & \\
\hline 2867 & & EF & 32. & $\mathrm{lb}$ & DEF & 26 & $.2 \mathrm{~b}$ \\
\hline 2865 & & & & & & & \\
\hline 2868 & & $\mathrm{EF}$ & $\mathrm{a}$ & & FG & $5 \mathrm{a}$ & \\
\hline 2921 & & & $25.66 \pm 1.18 \mathrm{a}$ & & EFG & $=11.7 \mathrm{a}$ & $1.7 \mathrm{a}$ \\
\hline 2866 & & & $27.10 \pm 1.16 \mathrm{a}$ & & $196.4 \pm 7.9 \mathrm{EFG}$ & $214.3 \pm 11.2 \mathrm{a}$ & $\pm 11.2 \mathrm{a}$ \\
\hline 2920 & & & $24.79 \pm 1.35 \mathrm{a}$ & & $3.3 \pm 9.7 \mathrm{EFG}$ & $189.7 \pm 13.6 \mathrm{a}$ & 186.9 \\
\hline 2551 & owe Ramı & & $23.10 \pm 1.22 \mathrm{a}$ & & EFG & $176.1 \pm 12.9 \mathrm{a}$ & $191.4 \pm 12.9 \mathrm{a}$ \\
\hline 2925 & & $84 \pm 0.8 \mathrm{DEF}$ & $24.59 \pm 1.15 \mathrm{a}$ & $23.11 \pm 1.12 \mathrm{a}$ & $184.2 \pm 8.2 \mathrm{EFG}$ & $191.9 \pm 11.6 \mathrm{a}$ & $176.5 \pm 11.6 \mathrm{a}$ \\
\hline & & & & & & & \\
\hline 3082 & Elbląg & $22.29 \pm 0.74 \mathrm{~F}$ & $22.24 \pm 1.04 \mathrm{a}$ & $22.33 \pm 1.04 \mathrm{a}$ & $168.3 \pm 7.9 \mathrm{G}$ & $167.8 \pm 11.1 \mathrm{a}$ & $168.8 \pm 11.1$ \\
\hline
\end{tabular}

${ }^{1}$ means with the same capital letter in columns and ${ }^{2}$ means with the same lowercase letter in rows were not significantly different at $p$ $\leq 0.05$. 
Table 4. Means, standard errors (SE) and homogenous groups for buds at stage 5 of flushing with reference to provenances $(M)$, seed orchard sector $(S)$, bud type $(B)$ and the $S \times B$ interaction ( $\mathrm{Nd}$ - number of days; Tcum - cumulated temperature)

\begin{tabular}{|c|c|c|}
\hline \multirow{2}{*}{ Source of variation } & $\mathrm{Nd}$ & Tcum \\
\hline & Mean \pm SE & Mean \pm SE \\
\hline \multicolumn{3}{|c|}{ Plus tree provenances $M$} \\
\hline Stare Jabłonki & $30.47 \pm 0.45 \mathrm{~A}^{1}$ & $244.58 \pm 4.07 \mathrm{~A}$ \\
\hline Strzałowo & $30.50 \pm 0.68 \mathrm{~A}$ & $241.87 \pm 6.15 \mathrm{AB}$ \\
\hline Dobrocin & $28.33 \pm 0.43 \mathrm{~B}$ & $225.86 \pm 4.09 \mathrm{BC}$ \\
\hline Nowe Ramuki & $27.58 \pm 0.53 \mathrm{BC}$ & $215.47 \pm 5.04 \mathrm{CD}$ \\
\hline Młynary & $27.01 \pm 0.27 \mathrm{BC}$ & $214.79 \pm 2.60 \mathrm{CD}$ \\
\hline Elbląg & $26.07 \pm 0.36 \mathrm{C}$ & $205.20 \pm 3.52 \mathrm{D}$ \\
\hline \multicolumn{3}{|c|}{ Sector $S$} \\
\hline No. 5 & $30.36 \pm 0.29 \mathrm{~A}$ & $242.48 \pm 2.66 \mathrm{~A}$ \\
\hline No. 3 & $26.34 \pm 0.22 \mathrm{~B}$ & $206.77 \pm 2.16 \mathrm{~B}$ \\
\hline \multicolumn{3}{|c|}{ Bud type $B$} \\
\hline Apical & $29.95 \pm 0.28 \mathrm{~A}$ & $242.57 \pm 2.58 \mathrm{~A}$ \\
\hline Axillary & $26.70 \pm 0.26 \mathrm{~B}$ & $206.68 \pm 2.58 \mathrm{~B}$ \\
\hline \multicolumn{3}{|c|}{ Sector $\times$ bud type $S \times B$} \\
\hline sector 3/apical buds & $28.45 \pm 0.32 \mathrm{~b} \mathrm{~A}^{2}$ & $227.13 \pm 3.05$ a A \\
\hline sector 3/axillary buds & $24.39 \pm 0.29 \mathrm{~b} \mathrm{~B}$ & $186.42 \pm 3.05$ a A \\
\hline sector $5 /$ apical buds & $31.53 \pm 0.42 \mathrm{a} \mathrm{A}$ & $258.02 \pm 3.77 \mathrm{a} \mathrm{A}$ \\
\hline sector $5 /$ axillary buds & $29.23 \pm 0.41 \mathrm{a} \mathrm{B}$ & $226.95 \pm 3.77$ a A \\
\hline $\begin{array}{l}\text { eans with the same } \\
\text { at } p \leq 0.05 \text { (i.e. in } \\
\text { source of variation } \\
\text { means with the sar } \\
\text { ferent at } p \leq 0.05\end{array}$ & $\begin{array}{l}\text { al letter are not si } \\
\text { parison of bud typ } \\
\text { eans with the sam } \\
\text { wercase letter are }\end{array}$ & $\begin{array}{l}\text { ignificantly different } \\
\text { pes within the same } \\
\text { ne capital letter and } \\
\text { not significantly dif- } \\
\text { bud types within a }\end{array}$ \\
\hline
\end{tabular}

and the course of the air temperature revealed a varying order of this effect on individual clones and provenances (Tables 1 and 3 ). In contrast, clones from Elbląg completed bud flushing significantly earlier compared to those of Dobrocin (Tables 3 and 4 ). At the same time, no differences were found between clones from Elbląg and clones from Nowe Ramuki and Młynary. In terms of bud flushing period, significant differences (8-9 days) were found between clones of the same provenance, e.g. clone 2862 derived from a plus tree from Młynary achieved flushing stage 5 in 32.9 days, while clone 2920 from Młynary took 24.75 days (Table 3 ). Similar patterns were observed in clones from Elblag provenance; clone 3081 from Elbląg achieved flushing stage 5 in 31 days, whereas clone 3082 from Elbląg took 22 days (Table 3 ).

On average, in sector no. 5, bud flushing was completed in 30.36 days, and in sector no. 3 , apical and axillary buds completed development in time intervals 3 days and 5 days shorter, respectively. Nonetheless, this difference was not observed among all clones examined. For example, all apical and axillary buds among Elbląg clones flushed within a significantly shorter period of time when compared to clones from other provenances studied (Tables 3 and 4).
Table 5. Influence of effects specified in Model 3 on differences between bud type development dynamics; Nd_apax and $\mathrm{T}_{\text {cum_ }}$ ap-ax are the differences between number of days and cumulated temperature, respectively, required by apical and axillary buds to achieve the final stage of bud development; Num DF - numerator degree of freedom; Den DF - denominator degree of freedom; F - test statistics; $p-p$ value)

\begin{tabular}{lccccccc}
\hline \multirow{2}{*}{$\begin{array}{l}\text { Source of } \\
\text { variation }\end{array}$} & \multirow{2}{*}{ Num } & Den & \multicolumn{2}{c}{ Nd_ap-ax } & \multicolumn{2}{c}{$\mathrm{T}_{\text {cum_ap-ax }}$} \\
\cline { 5 - 8 } & DF & DF & $\mathrm{F}$ & $\mathrm{p}$ & \multicolumn{1}{c}{$\mathrm{F}$} & $\mathrm{p}$ \\
\hline $\begin{array}{l}\text { Provenance of } \\
\text { plus tree } M\end{array}$ & 5 & 294 & 15.20 & $<0.001$ & 10.98 & $<0.001$ \\
$\begin{array}{l}\text { Clone(prove- } \\
\text { nance) } C(M)\end{array}$ & 25 & 294 & 5.06 & $<0.001$ & 4.40 & $<0.001$ \\
Sector $S$ & 1 & 294 & 9.57 & 0.002 & 3.15 & 0.077 \\
\hline
\end{tabular}

In both seed orchard sectors, irrespective of the examined type of European larch buds (apical or axillary), no significant correlations were found between daily mean air temperatures and bud flushing (i.e. the average bud stage; $p>0.05)$, both for clones and provenances in sectors. However, a significant relationship $(p<0.001)$ was found between cumulative air temperature and both bud types development in trees growing in both sectors.

In terms of the cumulative temperature required to achieve the final stage of bud development, most effects specified in Model 2 were significant, except the interaction effect between sector and bud type (Table 2$)$. Provenance Stare Jabłonki $\left(\mathrm{T}_{\text {cum }}=\right.$ $\left.244.58^{\circ} \mathrm{C}\right)$ was significantly different from provenance Elbląg $\left(\mathrm{T}_{\text {cum }}=205.2^{\circ} \mathrm{C}\right)$, with a difference in $\mathrm{T}_{\text {cum }}$ of $39.4^{\circ} \mathrm{C}$ (Table 4 ); however, particular clones showed a greater gap, e.g. Młynary $2862\left(269.4^{\circ} \mathrm{C}\right)$ and Elblagg $3082\left(168.3^{\circ} \mathrm{C}\right)$, with a difference in $\mathrm{T}_{\text {cum }}$ of $101.1^{\circ} \mathrm{C}$ (Table 3 ).

Significant differences were found between provenances, clones and tested sectors in terms of a difference in number of days necessary for the full development of apical buds compared to axillary buds (Table 5). Differences in total daily temperature required for the development of apical buds compared to axillary buds between provenances and clones were observed; however, there were not differences between sectors (Table 5).

The Młynary clones differed significantly in terms of the number of days to achieve full development of the tested bud types (Table 6). Clones 2867, 2919 were characterized by a greater difference in the full development between both bud types compared to the clones 2860, 2862, 2863, 2866, 2868, 2920 and 2921. Clone 2864 differed in this respect from clones 2868, 2920 and 2921. Clones within other provenances did not differ in terms of the difference in the number of days for the full development between the apical and axillary buds.

Also, in the provenance Młynary, some clones differed significantly in terms of cumulative air 
Table 6. Means, standard errors (SE) and homogeneous groups of clones in terms of differences between number of days $\left(\mathrm{Nd} \_a p-a x\right)$ and cumulated temperature $\left(\mathrm{T}_{\text {cum_- }}\right.$ ap-ax), respectively, required by apical (ap) and axillary (ax) buds to achieve the final stage of bud development; means with the same capital letter in columns are not significantly different at $\mathrm{p} \leq 0.05$

\begin{tabular}{|c|c|c|c|}
\hline Clone No. & Provenance of plus tree & Nd_ap-ax & $\mathrm{T}_{\text {cum_ap-ax }}$ ap \\
\hline 3076 & Dobrocin & $7 \pm 1.4 \mathrm{ABCDE}$ & $67.8 \pm 14.7 \mathrm{ABCD}$ \\
\hline 3077 & Dobrocin & $5.1 \pm 1.4 \mathrm{ABCDEF}$ & $50.9 \pm 14 \mathrm{ABCD}$ \\
\hline 3078 & Dobrocin & $6.9 \pm 1.3 \mathrm{ABCDE}$ & $65.4 \pm 13.4 \mathrm{ABCD}$ \\
\hline 3079 & Dobrocin & $8.6 \pm 1.3 \mathrm{ABC}$ & $79.4 \pm 13.4 \mathrm{ABC}$ \\
\hline 2925 & Elbląg & $1.4 \pm 1.4 \mathrm{DEF}$ & $15.4 \pm 14 \mathrm{CD}$ \\
\hline 2926 & Elbląg & $0.2 \pm 1.6 \mathrm{DEF}$ & $15.9 \pm 16.4 \mathrm{CD}$ \\
\hline 2927 & Elbląg & $2.8 \pm 1.6 \mathrm{BCDEF}$ & $30.6 \pm 16.4 \mathrm{BCD}$ \\
\hline 3081 & Elbląg & $4.8 \pm 1.3 \mathrm{ABCDEF}$ & $59.2 \pm 13.4 \mathrm{ABCD}$ \\
\hline 3082 & Elbląg & $-0.1 \pm 1.3 \mathrm{EF}$ & $-1 \pm 13.4 \mathrm{D}$ \\
\hline 3296 & Elbląg & $-0.4 \pm 1.3 \mathrm{~F}$ & $-4.4 \pm 13.4 \mathrm{D}$ \\
\hline 2860 & Młynary & $3.5 \pm 1.4 \mathrm{BCDEF}$ & $31.1 \pm 14 \mathrm{BCD}$ \\
\hline 2861 & Młynary & $6.3 \pm 2.3 \mathrm{ABCDEF}$ & $70.2 \pm 23.4 \mathrm{ABC}$ \\
\hline 2862 & Młynary & $3.1 \pm 1.4 \mathrm{BCDEF}$ & $42.7 \pm 14 \mathrm{ABCD}$ \\
\hline 2863 & Młynary & $3 \pm 1.4 \mathrm{BCDEF}$ & $36.3 \pm 14 \mathrm{BCD}$ \\
\hline 2864 & Młynary & $10.5 \pm 1 . \mathrm{AB}$ & $103.9 \pm 14 \mathrm{AB}$ \\
\hline 2865 & Młynary & $7.6 \pm 1.4 \mathrm{ABCD}$ & $66 \pm 14.8 \mathrm{ABCD}$ \\
\hline 2866 & Młynary & $3.5 \pm 1.3 \mathrm{BCDEF}$ & $35.8 \pm 13.4 \mathrm{BCD}$ \\
\hline 2867 & Młynary & $11.2 \pm 1 . \mathrm{A}$ & $109.1 \pm 13 . \mathrm{AB}$ \\
\hline 2868 & Młynary & $1.6 \pm 1.4 \mathrm{CDEF}$ & $13.8 \pm 14 \mathrm{CD}$ \\
\hline 2919 & Młynary & $12.1 \pm 1.4 \mathrm{~A}$ & $116.5 \pm 14 . \mathrm{A}$ \\
\hline 2920 & Młynary & $0 \pm 1.6 \mathrm{DEF}$ & $2.8 \pm 16.4 \mathrm{CD}$ \\
\hline 2921 & Młynary & $0.2 \pm 1.4 \mathrm{DEF}$ & $5.6 \pm 14.1 \mathrm{CD}$ \\
\hline 2549 & Nowe Ramuki & $1.6 \pm 1.5 \mathrm{CDEF}$ & $17.6 \pm 15.5 \mathrm{CD}$ \\
\hline 2550 & Nowe Ramuki & $1.2 \pm 1.3 \mathrm{DEF}$ & $22.7 \pm 13.4 \mathrm{CD}$ \\
\hline 2551 & Nowe Ramuki & $-2.3 \pm 1.5 \mathrm{~F}$ & $-15.3 \pm 15.5 \mathrm{D}$ \\
\hline 2231 & Stare Jabłonki & $3 \pm 1.5 \mathrm{BCDEF}$ & $33.5 \pm 15.5 \mathrm{BCD}$ \\
\hline 2514 & Stare Jabłonki & $6.8 \pm 1.3 \mathrm{ABCDE}$ & $68.2 \pm 13.4 \mathrm{ABCD}$ \\
\hline 2515 & Stare Jabłonki & $4.9 \pm 1.3 \mathrm{ABCDEF}$ & $55.9 \pm 13.4 \mathrm{ABCD}$ \\
\hline 2516 & Stare Jabłonki & $3.8 \pm 1.3 \mathrm{BCDEF}$ & $47.1 \pm 12.9 \mathrm{ABCD}$ \\
\hline 3083 & Strzałowo & $2.1 \pm 1.4 \mathrm{CDEF}$ & $27.7 \pm 14 \mathrm{CD}$ \\
\hline 3084 & Strzałowo & $0.3 \pm 1.5 \mathrm{DEF}$ & $8.1 \pm 15.5 \mathrm{CD}$ \\
\hline
\end{tabular}

temperature required to achieve full development of apical buds compared to axillary buds. For clone 2919, the difference in the cumulated temperature required to develop apical buds compared to axillary buds was greater than that of clones 2860 , 2863, 2866, 2868, 2920 and 2921. Clones 2864 and 2867 differed significantly from clones 2868, 2920 and 2921 (Table 6).

Dobrocin, Młynary and Stare Jablonki provenances required more time to develop apical buds compared to axillary buds than the provenances Elblag, Strzałowo and Nowe Ramuki (Table 7). The average difference between the number of days required by both bud types in sector no. 3 was over 4 days and significantly higher than that in sector no. 5, where the average was 2.45 days. Similarly, apical buds from clones from Dobrocin, Młynary and Stare Jabłonki provenances required a cumulative temperature about $50^{\circ} \mathrm{C}$ higher compared to axillary lateral buds from the provenances of Elblag, Strzałowo and Nowe Ramuki (Table 7).
Table 7. Means, standard errors (SE) and homogenous groups for provenances $(M)$ and seed orchard sectors $(S)$ in terms of differences between number of days (Nd_ap-ax) and cumulated temperature ( $\mathrm{T}_{\text {cum_ap-ax }}$ ), respectively, required by apical (ap) and axillary (ax) buds to achieve the final stage of bud development; means with the same capital letter in columns are not significantly different at $\mathrm{p} \leq 0.05$

\begin{tabular}{ccr}
\hline \multirow{2}{*}{ Source of variation } & \multicolumn{1}{c}{ Nd_ap-ax } & \multicolumn{1}{c}{$\mathrm{T}_{\text {cum_ap-ax }}$} \\
\cline { 2 - 3 } & Mean $\pm \mathrm{SE}$ & \multicolumn{1}{c}{ Mean $\pm \mathrm{SE}$} \\
\hline \multicolumn{3}{c}{ Plus tree provenances $M$} \\
\hline Dobrocin & $6.92 \pm 0.68 \mathrm{~A}$ & $65.85 \pm 6.98 \mathrm{~A}$ \\
Młynary & $5.22 \pm 0.43 \mathrm{~A}$ & $52.81 \pm 4.44 \mathrm{~A}$ \\
Stare Jabłonki & $4.63 \pm 0.67 \mathrm{~A}$ & $51.19 \pm 6.94 \mathrm{~A}$ \\
Elbląg & $1.44 \pm 0.58 \mathrm{~B}$ & $19.26 \pm 6.00 \mathrm{~B}$ \\
Strzałowo & $1.21 \pm 1.02 \mathrm{~B}$ & $17.93 \pm 10.48 \mathrm{~B}$ \\
Nowe Ramuki & $0.17 \pm 0.83 \mathrm{~B}$ & $8.31 \pm 8.58 \mathrm{~B}$ \\
\hline Sector $S$ & & \\
\hline No. 3 & $4.08 \pm 0.36 \mathrm{~A}$ & $40.71 \pm 3.67 \mathrm{~A}$ \\
No. 5 & $2.45 \pm 0.44 \mathrm{~B}$ & $31.07 \pm 4.54 \mathrm{~A}$ \\
\hline
\end{tabular}




\section{Discussion}

\section{Site effects}

Forest tree phenologies can be predicted with the use of mechanistic models (Chuine et al., 2003), in which parameters such as temperature, cumulative temperatures and photoperiod play a key role (Partanen et al., 2001; Migliavacca et al., 2008; Linkosalo et al., 2009). Additionally, temperature decreases and light quality could also impulses to start bud burst (Linkosalo \& Lechowicz, 2006). The seed orchard location in this study is representative of the climatic conditions of the East European Plain (the Mazury-Podlasie nature-forest region; Kondracki, 2013). Therefore, it can be assumed that climatic as well as habitat conditions of plus trees and clones in the Łegajny seed orchard were fairly uniform, excluding the Elbląg and Młynary plus stands, which grow under the influence of the Baltic Sea climate.

In the present study, some differences were found between seed orchard sectors with regard to flushing of apical and axillary buds to certain developmental stages (in the 1-5-stage scale). The mean times required to reach full bud flushing were not significantly affected by daily air temperature (except on axillary buds of European larch clones growing in seed orchard sector no. 5). These differences between the two sectors of the seed orchard (which differed considerably in soil moisture) indicate that both soil conditions and air temperature can affect bud flushing, irrespective of clone phenotypic traits. Wilczyński \& Wertz (2012) stated that warm and cloudless periods at the beginning of the vegetation season (i.e. in March) had beneficial effects on tree conditions and, consequently, on potential tree growth. Worall (1993) emphasised the substantial influence of temperature on bud burst in subalpine larch (Larix lyallii).

In spring, trees begin development earlier in the moderate climate zone of the southern provenances than in the northern provenances and are therefore more susceptible to spring frost (Lukkarinen et al., 2014). Eysteinsson et al. (2009) described the genus Larix as frequently being injured by winter and spring frosts; however, different species differ in frost resistance, and the least resistant trees were from the far-east provenances. Young Larix decidua trees are commonly destroyed by frost in the northern provinces of Europe (Carswell \& Morgenstern, 1995; Karlman \& Karlsson, 2013) because a lower cumulative temperature is necessary to trigger bud development (Eriksson et al., 2006). Similarly, Chmura et al. (2011) found that Scots pine trees from harsher climate zones develop buds earlier than those from temperate zones.

\section{Genetic effects}

For individual clones, there were clear differences in bud development. At the same time, a variable effect of air temperature on the development of buds was observed. The differences in bud flushing were significant among the following groups: European larch clones originating from plus trees growing in selected seed stands situated in different locations (i.e. clones of different provenances); clones of the same provenance and seed orchard sectors. The variability of larch phenological traits has been described by Schreiber (1964), who found that the sequence of spring bud burst among $L$. decidua provenances depended on local conditions for tree growth. Indeed, subsequent work has shown significant interactions between genotypes of several coniferous tree species (e.g. Pinus sylvestris, P. taeda and P. banksiana) and their growing sites (the so-called "experimental plot location"; Li \& McKeand, 1989; Woolaston et al., 1991). Such interactions with growth environments indicate that phenological traits in European larch are shaped by a variety of factors, of which climatic aspects (especially temperature and rainfall) seem to play a key role (Danek, 2009; Markiewicz, 2010). However, the present study revealed a significant relationship between cumulative temperature and the timing of bud development completion to the stage of elongate needles in open rosettes (stages $0-5$ ).

\section{Differences between apical and axillary buds}

There were remarkable differences between apical and axillary buds with regard to bud flushing (i.e. average number of days needed to complete development and reach the stage of elongated needles in an open rosette). For the time required to reach the fifth and last stage of bud flushing, an important differences in cumulated temperature between apical and axillary buds were observed, either at the level of individual clones (taken as a whole) plus stands or the seed orchard sectors. However, given the progression of their first stage of development (stages 0-3), clones from Stare Jabłonki provenance are likely resistant to spring frost because their buds developed most slowly; in contrast, clones from Elbląg are likely susceptible to frost. Differences in susceptibility of both axillary and apical buds among clones were also found. The final stage may be determined by photosynthetic activity, but earlier phases may also have biological significance, i.e. before reaching phase 2 or 3 , buds may have a higher probability of being damaged by frost. In the Łegajny seed orchard, among European larch clones derived from plus trees growing in regions with similar climatic conditions, local 
variability of terrain and soil humidity conditions of the seed orchard sectors may strengthen the effect of temperature decreases and therefore influence bud development. These factors should be considered in investigations of spring frost susceptibility of particular clones. Sector no. 3 represented conditions consistent with most of the tęgajny area, whereas sector no. 5 contained more humid soils as it was periodically flooded by a natural spring. In sector no. 5 , the bud burst period was longer (on average three days) compared to that in sector no. 3. In the latter, apical buds completed their development on average two days earlier than axillary buds, whereas in section no. 5, the difference was four days. The interaction between sector and bud type for cumulative temperature required to achieve the final stage of bud was not significant. Notwithstanding, the buds in sector 5 required a higher accumulated temperature than those in sector 3 . In other words, the apical buds (regardless of sector) needed a higher cumulative temperature than the axillary buds. It is therefore likely that soil humidity conditions in sector no. 5 have diminished the effect of air temperature, thus delaying the bud burst process.

Gömöry \& Paule (1993) showed that among different provenances in Slovakia, results are considerably influenced $(27 \%)$ by the conditions of seed orchard establishment, in particular tree planting techniques. Such effects could also be expected in Poland's seed orchards (Burczyk et al., 2000; Przybylski, 2015).

\section{Concluding remarks}

In the presented research (spring 2014, in northern Poland), significant differences in the timing of bud burst were found between apical and axillary buds of European larch clones, depending on clones, clone provenances and tree growing sites. These differences suggest the presence of a phylogenetic strategy of more frost-resistant clones or provenances of Larix to avoid damages in the early stages of bud flushing.

The conditions for tree growth (air temperature and periodical changes of soil moisture within seed orchard sector) significantly influenced bud burst in European larch clones, especially in the early stages of bud development. In the sector periodically flooded by nearby bog-springs (no. 5, which was thus frequently excessively damp), bud flushing was significantly delayed when compared to sector no. 3 which presented typical conditions for tree growth. However, differences between bud types in later-flushing clones decreased with time.

Cumulative temperature seems to be a good indicator to assess frost-susceptible or -resistant clones/provenances. In this study, the difference in cumulative temperature between frost susceptible and frost resistant clones was $101.1^{\circ} \mathrm{C}$ (Elbląg 3082 vs Młynary 2862) and between provenances $39.2^{\circ} \mathrm{C}$ (Elbląg vs Stare Jabłonki), respectively. The provenance Elbląg is situated in a mild climate region of Gdańskie Lakes, whereas Stare Jabłonki is located in a more continental climate (Fig. 1), similar to the Łęgajny seed orchard area.

Mean daily air temperature influenced the completion of bud flushing in European larch clones growing under different soil moisture conditions. Clones 2925, 3082 and 3296 from Elbląg are likely to be susceptible to spring frost.-

\section{Acknowledgments}

The authors would like to thank Ms Marlena Sikorska from the Olsztyn Forest District for providing useful information. We also thank two anonymous reviewers for their valuable comments and suggestions. The study was a part of the Engineering Thesis of Mr Marcin Zagożdzon at the Department of Forestry and Forest Ecology, University of Warmia and Mazury in Olsztyn, under the supervision of C. Bystrowski and Z. Sierota.

\section{References}

Akaike H (1983) Information measures and model selection. Bulletin of the International Statistical Institute 44: 277-291.

Andrzejczyk T \& Bellon S (1999) Growth and quality of Polish provenances of 30-year-old larch on a provenance plot at Rogów. Sylwan 143: 5-19.

Burczyk J, Dzialuk A \& Lewandowski A (2000) Genetic variation of Scots pine (Pinus sylvestris L.) in Gniewkowo clonal seed orchard. Sylwan 7: 65-47.

Carswell CL \& Morgenstern EK (1995) Phenology and growth of nine larch species and hybrids tested in New Brunswick, Canada. General Technical Report - IRS USDA FS, INT-GTR-319: 318-322.

Chmielewski F-M \& Rötzer T (2001) Response of tree phenology to climate change across Europe. Agricultural and Forest Meteorology 108: 101112. doi:10.1016/S0168-1923(01)00233-7.

Chmura DJ, Rożkowski D \& Chałupka W (2011) Growth and phenology variation in progeny of Scots pine seed orchards and commercial seed stands. European Journal of Forest Research 131: 1229-1243.

Chuine I \& Cour P (1999) Climatic determinants of budburst seasonality in four temperate-zone tree species. New Phytologist 143: 339-349.

Danek M (2009) The influence of climate conditions on tree ring width of larch (Larix decidua Mill.) 
from the northern part of the Małopolska province. Sylwan 153: 768-776.

Eriksson G, Ekberg I \& Clapham D (2006) An introduction to forest genetics. Swedish University of Agricultural Sciences (SLU), Uppsala.

Eysteinsson T, Karlman L, Fries A, Martinsson O \& Skúlason B (2009) Variation in spring and autumn frost tolerance among provenances of Russian larches (Larix Mill.). Scandinavian Journal of Forest Research 24: 100-110.

Gauchat ME \& Pâques LE (2011) Indirect prediction of bud flushing from ex situ observation in hybrid larch (Larix decidua x L.kaempferi) and their parents. Environmental and Experimental Botany 70: 121-130. doi.org/10.1016/j.envexpbot.2010.08.001.

Gömöry D \& Paule L (1993) Inferences on mating system and genetic composition of a seed crop in the European larch (Larix decidua Mill.). Journal of Animal Breeding Genetics 46: 309-314.

Hänninen H (1995) Effects of climatic change on trees from cool and temperate regions: an ecophysiological approach to modelling of bud burst phenology. Canadian Journal of Botany 73: 183199. doi:10.1139/b95-022.

Hansen JN (1992) Effects of nutritional factors on frost hardening in Larix leptolepis (Sieb \& Zucc.) Gord. Scandinavian Journal of Forest Research 7: 183-192.

Jagielska A (2008) Application of genetic markers in species identification of European and Japanese larch and their hybrids. Forest Research Papers 69: 21-25.

Karki D \& Lee SJ (2000) Early selection in tree breeding: research experience of Sitka spruce, using farm-field site technique: Proceedings of the "8th International Workshop of BIOREFOR" (ed. by MS Bista, RB Joshi, SM Amatya, AV Parajuli, MK Adhikari, HK Saiju, R Thakur, K Suzuki \& K Ishii) Kathmandu (Nepal), 28 Nov. -2 Dec., pp. 98-104.

Karlman L \& Karlsson Ch (2013) En beskrivning av SLU:s proveniensserie med europeisk lärk (Larix decidua). SLU Simakserien, Report 8: 1-29.

Kauhanen M, Vainio EJ, Hantula J \& Niemelä P (2006) Endophytic fungi in Siberian larch (Larix sibirica) needles. Forest Pathology 36: 434-446. doi:10.1111/j.1439-0329.2006.00472.x.

Kondracki J (2013) Regional geography of Poland. PWN Warszawa.

Kulej M (2006) Resistance of larches of Polish provenances to larch canker Lachnellula willkommii (Hartig.) Dennis under mountain conditions of the Sącz Beskid. Electronic Journal of Polish Agricultural Universities 9. http://www.ejpau.media.pl/ volume9/issue2/art-29.html.
Li B \& McKeand SE (1989) Stability of loblolly pine families in the southeastern U.S. Silvae Genetica 38: 96-101.

Linkosalo T, Häkkinen R, Terhivuo J, Tuomenvirta H \& Hari P (2009) The time series of flowering and leaf bud burst of boreal trees (1846-2005) support the direct temperature observations of climatic warming. Agricultural and Forest Meteorology 149: 453-461. doi:10.1016/j.agrformet.2008.09.006.

Linkosalo T \& Lechowicz MJ (2006) Twilight far-red treatment advances leaf bud burst of silver birch (Betula pendula). Tree Physiology 26: 1249-1256.

Littell RC, Stroup WW \& Freund RJ (2002) SAS for linear models. 4rd edition. SAS Institute Inc. Cary, NC.

Lukkarinen AJ, Ruotsalainen S, Peltola H \& Nikkanen T (2013) Annual growth rhythm of Larix sibirica and Larix gmelinii provenances in a field trial in southern Finland. Scandinavian Journal of Forest Research 28: 518-532.

Lukkarinen AJ, Ruotsalainen S, Peltola H \& Nikkanen T (2014) Bud set and autumn coloration of Larix sibirica and Larix gmelinii provenances in a field trial in southern Finland. Scandinavian Journal of Forest Research 29: 27-40.

Markiewicz P (2010) The influence of climatic factors and treatments stimulating the flowering in European larch seed plantations and seed plantation crops. PhD thesis, Forest Research Institute in Sękocin Stary.

Matras J (2001) Provenance studies of the Forest Research Institute on the European larch in 19482000. Prace Instytutu Badawczego Leśnictwa Ser A 1: 41-63.

McCullagh P \& Nelder JA (1989) Generalized linear models. 2nd ed. Chapman and Hall, London.

Migliavacca M, Cremonese E, Colombo R, Busetto L, Galvagno M, Ganis L, Meroni M, Pari E, Rossini M, Siniscalco C \& Morra di Cella U (2008) European larch phenology in the Alps: can we grasp the role of ecological factors by combining field observations and inverse modelling? International Journal of Biometeorology 52: 587-605.

Moser L, Fonti P, Büntgen U, Esper J, Luterbacher J, Franzen J \& Frank D (2010) Timing and duration of European larch growing season along altitudinal gradients in the Swiss Alps. Tree Physiology 30: 225-233.

Nelder JA \& Weddenburn RWM (1972) Generalized linear models. Journal of the Royal Statistical Society. Series A (General) 135: 370-384.

Owens JN \& Molder M (1979) Bud development in Larix occidentalis. I. Growth and development of vegetative long shoot and vegetative short shoot buds. Canadian Journal of Botany 57: 687-700. doi:10.1139/b79-088. 
Partanen J, Leinonen I \& Repo T (2001) Effect of accumulated duration of the light period on bud burst in Norway spruce (Picea abies) of varying ages. Silva Fennica 35: 111-117.

Przybylski P (2015) Are we narrowing genetic variability in seed orchards? An attempt to answer, based on the analysis of microsatellite DNA of grafts growing in Scots pine (Pinus sylvestris L.) seed orchard in the Forest District Susz. Forest Research Papers 76: 240-249. doi:10.1515frp-2015-0023.

Rossi S, Rathgeber CBK \& Deslauriers A (2009) Comparing needle and shoot phenology with xylem development on three conifer species in Italy. Annals of Forest Sciences 66: 1-8. doi:10.1051/ forest/2008088.

Rötzer T, Grote R \& Pretzsch H (2004) The timing of bud burst and its effect on tree growth. International Journal of Biometeorology 48: 109-118. doi:10.1007/s00484-003-0191-1.

SAS Institute Inc., 2010; 2011. SAS/STAT 9.2; 9.3 User's Guide. SAS Institute Inc., Cary, NC.

Schreiber M (1964) Über neue forschungsergebnisse auf dem gebiete der lärchenrassenbiologie. Schweizerische Zeitschrift für Forstwesen 115: 44-74.

Schueler S \& Liesebach M (2016) Latitudinal population transfer reduces temperature sum requirements for bud burst of European beech. Plant
Ecology 216: 111-122. doi:10.1007/s11258-0140420-1.

Simak M (1970) Photo- and thermoperiodic responses of different larch provenances (Larix decidua Mill.). Studia Forestalia Suecica 86: 1-32.

Stokes ME, Davies CS \& Koch GG (2000) Categorical data analysis using the SAS System. 2nd edition. SAS Institute Inc. Cary, NC.

Szeligowski H \& Bolibok L (2008) The growth parameters of larch species of Polish origins aged at 40 years on the experimental plot in Rogów. Forest Research Papers 69: 285-290.

Szumowski B (1995) Increasing the resistance of different provenances of Polish larch by means of tissue stimulation to production of phenolic substances that limit the magnitude of infection with Lachnellula willkommii (Hahn et Ayers) Dharen. Forestry and Wood Technology 46: 3-12.

Wilczyński S \& Wertz B (2012) Sygnał klimatyczny w seriach przyrostów radialnych jodły pospolitej oraz modrzewia europejskiego. Studia Materiały CEPL Rogów 14/1: 66-74. http://cepl.sggw.waw. pl/sim/pdf/sim30_pdf/sim30_S_Wilczynski.pdf.

Woolaston RR, Kanowski PJ \& Nikles DG (1991) Genotype-environment interactions in Pinus caribaea var. hondurensis in Queensland, Australia. I. Population $\times$ site interactions. Silvae Genetica 40: $224-228$. 